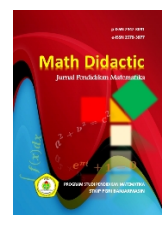

MATH DIDACTIC: JURNAL PENDIDIKAN MATEMATIKA

Volume 4 Edisi Dies Natalis XXXII, halaman 261 - 269

Tersedia Daring padahttp://jurnal.stkipbjm.ac.id/index.php/math

\title{
MENINGKATKAN PROSES DAN HASIL BELAJAR MATEMATIKA SISWA PADA MATERI PERSAMAAN LINIER DUA VARIABEL MELALUI MODEL PEMBELAJARAN THINK TALK WRITE (TTW)
}

\section{IMPROVING THE PROCESS AND RESULT OF LEARNING MATHEMATICS IN THE MATERIAL OF LINIER EQUATION TWO-VARIABLES THROUGH LEARNING MODELS THINK TALK WRITE (TTW)}

Sri Wahyuningsih

SMP Negeri 6 Pelaihari Kabupaten Tanah Laut sriwahyuningsih645@ymail.com

\begin{abstract}
Abstrak: Penelitian ini bertujuan untuk (1) Mendeskripsikan ketercapaian pelaksanaan Model Pembelajaran Think Talk Write (TTW), (2) Meningkatkan aktivitas siswa (3) Hasil belajar siswa, dan (4) Mendeskripsikan respon siswa terhadap Model Pembelajaran Think Talk Write (TTW) pada materi Persamaan Linier Dua Variabel. Hasil penelitian menunjukkan bahwa (1) keterlaksanaan Model Pembelajaran Think Talk Write (TTW) pada materi Persamaan Linier Dua Variabel telah dilakukan oleh guru seluruhnya dari 80,77\% pada siklus I, 96,1\% pada siklus II, mengalami peningkatan $100 \%$ pada siklus III dengan kreteria sangat tinggi, (2) Aktivitas siswa 49,75\% pada siklus I, 75,75\% pada siklus II mengalami peningkatan pada siklus III 91,50\% dengan kreteria sangat aktif, (3) Hasil belajar siswa pada materi persamaan linier Dua Variabel setelah menggunakan model pembelajaran Think Talk Write (TTW) menunjukkan adanya peningkatan dari 66,40 pada siklus I, 72,15 pada siklus II menjadi 83,55 pada siklus III dengan ketuntasan klasikal masing-masing 55\%, 70\% dan 100\%. (4) respon siswa 95\% menyatakan bahwa mereka sangat senang belajar materi persamaan linier Dua Variabel dengan menggunakan model pembelajaran Think Talk Write (TTW). Sehingga dapat disimpulkan bahwa Model Pembelajaran Think Talk Write (TTW) dapat meningkatkan proses dan hasil belajar matematika siswa kelas VIIIA SMP Negeri 6 Pelaihari Pada Materi Persamaan Linier Dua Variabel.
\end{abstract}

Kata Kunci: proses, hasil belajar, Think Talk Write (TTW)

Abstract: This research aim to (1) describe the achievement of the implementation of Think Talk Write (TTW) Learning Model, (2) Increasing student activity (3) Student learning outcomes, and (4) Describing student responses to Think Talk Write (TTW) Learning Model in the material Two Variable Linear Equations. The results showed that (1) the implementation of the Think Talk Write (TTW) Learning Model in the Two-Variable Linear Equation material was carried out by the teacher entirely from $80.77 \%$ in the first cycle, $96.15 \%$ in the second cycle, experiencing a 100\% increase in the cycle III with criteria very high, (2) Student activity $49.75 \%$ in the first cycle, $75.75 \%$ in the second cycle experienced an increase in the third cycle of $91.50 \%$ with a very active criteria, (3) Student learning outcomes in the two-variable linear equation material after using the model Think Talk Write (TTW) learning shows the existencean increase from 66.40 in the first cycle, 72.15 in the second cycle to 83.55 in the third cycle with classical completeness of 55\%,70\% and $100 \%$ respectively. (4) responses of $95 \%$ students stated that they were very happy to learn the material of two-variable linear equations using the learning modelThink Talk Write (TTW).so that it can be concluded that the Think Talk Write (TTW) Learning Model can improve the process and results of mathematics learning in class VIIIA Pelaihari SMP Negeri 6 in the Two Variable Linear Equation Material.

Keywords: process, result learning, Think Talk Write (TTW)

Cara Sitasi: Wahyuningsih, S. (2018). Meningkatkan proses dan hasil belajar matematika siswa pada materi persamaan linier dua variabel melalui model pembelajaran Think Talk Write (TTW) di kelas VIIIA SMP Negeri 6 Pelaihari. Math Didactic: Jurnal Pendidikan Matematika, 4 Edisi Dies Natalis XXXII, 261-269. 
Proses belajar mengajar didalamnya terdapat kegiatan guru dan kegiatan siswa, yang saling mendukung untuk ketercapaiannya sebuah tujuan. Kegiatan mengajar yang dilakukan oleh guru dan kegiatan belajar yang dilakukan oleh siswa mempengaruhi satu sama lain dalam memperlancar berlangsungnya proses pembelajaran (Isrok'atun, 2018, hal.1). Sehingga terjadilah interaksi antara guru dan siswa dalam pembelajaran yang saling mempengaruhi proses belajar itu sendiri. Dengan demikian didalam proses pembelajaran guru menjadi fasilitator bagi siswa dalam belajar. Demikian juga siswa harus dapat berlaku sebagai subyek yang belajar aktif.

Namun kenyataannya fakta yang terjadi dilapangan proses pembelajaran matematika baik yang dilakukan oleh guru maupun siswa belum dapat maksimal. Proses pembelajaran masih berpusat pada guru, dimana dalam menyampaikan proses pembelajaran guru masih menggunakan metode ceramah, sehingga berakibat siswa pasif dan tidak aktif di dalam pembelajaran. Karena siswa tidak terlibat langsung di dalam proses belajar mengajar.

Berdasarkan Hasil analisis ulangan harian matematika siswa kelas VIIIA SMP Negeri 6 Pelaihari Tahun Pelajaran 2017/2018 diketahui bahwa nilai rata-rata materi Sistem persamaam Linier Dua Variabel 45,43 sangat rendah karena berada di bawah Kriteria Ketuntasan Minimal (KKM) yang telah ditetapkan sekolah 65 . Rendahnya nilai Sistem Persamaam Linier Dua Variabel diduga disebabkan siswa kurang dapat berfikir ntuk memecahkan permasalahan yang diberikan. Siswa lambat didalam menerima pelajaran dan malas untuk berfikir menyelesaikan persoalan matematika karena tidak ada semangat untuk belajar matematika. Hal ini juga merupakan dampak dari terbiasanya siswa memperoleh pembelajaran dari guru yang hanya menggunakan metode ceramah.

Penggunaan metode ceramah ini bisa di variasikan dengan model pembelajaran yang lain, dimana modelmodel pembelajaran tersebut dipilih yang dapat meningkatkan aktivitas belajar siswa sehingga diharapkan hasil belajar siswa juga lebih meningkat. Menurut Huinker dan Laughlin (Huda, 2014, hal.218) strategi Think Talk Write (TTW) mendorong siswa untuk berfikir, berbicara, dan kemudian menuliskan suatu topik tertentu. Strategi ini digunakan untuk mengembangkan tulisan dengan lancar dan melatih bahasa sebelum dituliskan. Proses pembelajaran Think Talk Write (TTW) dapat membangun pemahaman melalaui berfikir, berbicara, menulis dengan melibatkan siswa dan dapat digunakan dalam pembelajaran matematika

Berdasarkan latar belakang diatas maka peneliti tertarik untuk meningkatkan proses dan hasil belajar matematika siswa pada persamaan linier dua variabel melalui model pembelajaran Think Talk Write (TTW).

Adapun tujuan dari penelitian ini adalah (1)mendeskripsikan ketercapaian pelaksanaan Model Pembelajaran Think Talk Write (TTW), (2) meningkatkan aktivitas siswa, (3) hasil belajar siswa, 
dan (4) mendeskripsikan respon siswa terhadap Model Pembelajaran Think Talk Write (TTW) pada materi Persamaan Linier Dua Variabel.

Menurut Rusman (2011, hal.4) Perencanan proses pembelajaran meliputi Silabus dan Rencana Pelaksanaan Pembelajaran (RPP) yang memuat indentitas mata pelajaran, Standar Kompetensi (SI), Kompetensi Dasar (KD), indikator pencapaian kompetensi, tujuan pembelajaran, materi ajar, alokasi waktu, metode pembelajaran, kegiatan pembelajaran, penilaian hasil belajar dan sumber belajar. Kegiatan pembelajaran merupakan proses pembelajaran untuk mencapai kompetensi dasar yang dilakukan secara interaktif, inspiratif, menyenangkan, menantang memotivasi peserta didik untuk berpartisipasi aktif, serta memberikan ruang yang cukup bagi prakarsa, kreativitas dan kemandirian sesuai dengan bakat, minat dan perkembangan fisik serta psikologi peserta didik. Kegiatan pembelajaran menggunakan metode yang disesuaikan dengan karakteristik peserta didik. Proses pembelajaran dirancang untuk mengembangkan kegemaran membaca, pemahaman beragam bacaan dan berekspresi dalam berbagai bentuk tulisan.

$$
\text { Isrok'atun (2018, hal.8) }
$$
mengatakan dalam proses pembelajaran terjadi interaksi antara guru dan siswa yang saling mempengaruhi. Oleh karena itu, terdapat tiga unsur penting dalam sebuah interaksi edukatif (interaksi dalam pembelajaran) yakni siswa, guru dan materi ajar sebagai pesan yang menjadi pembahasan selama proses pembelajaran. Interaksi antara guru dan siswa terlihat pada saat guru berperan sebagai fasilitator, monitor, dan evaluator saat proses pembelajaran berlangsung. Oleh karena itu guru seharusnya memberikan rangsangan agar siswa aktif melakukan kegiatan pembelajaran.

Hasil belajar adalah hasil yang diperoleh siswa setelah mengikuti suatu penjelasan materi tertentu dari mata pelajaran yang berupa data kuantitatif maupun kualitatif (Kunandar, 2008, hal.276). Hasil belajar merupakan suatu bentuk perubahan tingkah laku yang dinilai dengan standar penilaian yang dicapai.Menurut anas Sudijono (1996, hal.48) penilaian hasil belajar dituntut untuk mengevaluasi menyeluruh terhadap peserta didik, baik dari segi pemahamannya terhadap materi atau bahan pelajaran yang telah diberikan (aspek kognitif), maupun dari segi penghayatan (aspek afektif) dan pengamalannya (aspek psikomotor).

Penilaian dilakukan oleh guru terhadap hasil pembelajaran untuk mengukur tingkat pencampaian kompetensi peserta didik, serta digunakan sebagai bahan penyusunan laporan kemajuan hasil belajar, dan memperbaiki proses pembelajaran (Rusman, 2011, hal.13).

Model pembelajaran merupakan salah satu komponen pembelajaran yang menjadikan panduan dalam melakukan langkah-langkah kegiatan.dalam mengaplikasikan langkah-langkah model pembelajaran terdapat pendekatan, strategi, metode, teknik dan taktik yang digunakan guru untuk menunjang pembelajaran. Menurut 
Isrok'atun (2018, hal.154) dalam pembelajaran matematika, model TTW diterapkan melalui tiga kemampuan matematika yakni berfikir matematis, berbicara matematis, dan menulis matematis. Berpikir matematis diterapkan dengan memahami suatu peristiwa atau masalah matematis. Permasalahan matematis ini dikemas dalam masalah kehidupan. Dengan demikian, model TTW ini memiliki hubungan dengan kemampuan matematis.

Model pembelajaran TTW melibatkan empat tahap penting yang harus dikebangkan dan dilakukan dalam pembelajaran, yaitu :

\section{Berpikir (Think)}

Aktivitas berpikir dapat dilihat dari proses membaca suatu teks bacaan, kemudian membuat catatan apa yang telah dibaca. Membuat catatan kecil dapat meningkatkan siswa dalam berpikir dan menulis.

2. Berbicara (Talk)

Tahap selanjutnya adalah Talk yaitu berkomunikasi dengan menggunakan kata-kata dan bahasa yang mereka pahami. Proses komunikasi di dalam kelas dapat dilakukan dengan cara diskusi.

\section{Menulis (Write)}

Fase write yaitu menuliskan hasil diskusi atau pada lembar kerja siswa (LKS) yang disediakan. Aktivitas menulis berarti mengonstruksikan ide, karena setelah berdiskusi antar teman kemudian mengungkapkannya melalui tulisan.

4. Presentasi

Presentasi ini dimaksudnkan agar siswa dapat berbagi pendapat dalam ruang lingkup yang lebih besar, yaitu dengan teman satu kelas (Hamdayana, 2014, hal.216)

\section{Metode Penelitian}

Penelitian ini menggunakan pendekatan kualitatif dan kuantitatif. Jenis penelitian yang digunakan penelitian tindakan kelas (PTK). Setiap siklus meliputi tahapan yang saling berkaitan dan berkesinambungan, yaitu perencanaan (planning), tindakan (action), pengamatan (observasi), dan refleksi (reflection) (Atmono, 2009: 14). Penelitian ini dilaksanakan dalam 3 siklus, dengan tiga kali pertemuan.

Penelitian dilaksanakan di SMP Negeri 6 Pelaihari, Jl.Katunun Rt.3 Desa Telaga Kecamatan Pelaihari Kabupaten tanah Laut. Dengan subyek penelitian adalah siswa kelas VIIIA SMP Negeri 6 Pelaihari pada Semester 1 Tahun Pelajaran 2018/2019 yang berjumlah 20 orang, terdiri dari 11 orang laki-laki dan 9 orang perempuan. Peneliti terjun langsung sebagai perencana, pengajar, pengumpulan data, penganalisis data dan pelapor hasil penelitian. Pelaksanaan tindakan diamati oleh dua orang teman sejawat sebagai observer.

Dalam penelitian ini yang menjadi indikator keberhasilan adalah :

1. Keterlaksanaan model pembelajaran Think Talk Write (TTW) minimal rata-rata dilaksanakan $95 \%$ dan menunjukkan kreteria sangat tinggi.

2. Aktivitas siswa dalam model pembelajaran Think Talk Write (TTW) menunjukkan ketercapaian minimal $75 \%$ untuk setiap aktivitas 
dan menunjukkan kreteria sangat aktif.

3. Hasil belajar siswa mencapai ketuntasan klasikal $\geq 75 \%$ dengan KKM (Kriteria Ketuntasan Minimal) yang telah ditetapkan sekolah 65.

4. Respon siswa terhadap model pembelajaran Think Talk Write (TTW) menunjukkan respon yang positif, yaitu minimal $65 \%$ siswa menyatakan "Ya" pada setiap pernyataan respon siswa.

\section{Hasil Penelitian dan Pembahasan}

\section{Hasil}

A. Keterlaksanaan Pembelajaran

Hasil observasi keterlaksanaan pembelajaran dengan menggunakan Think Talk Write (TTW) pada tabel 1.

Tabel 1

Observasi Keterlaksanaan Think Talk Write (TTW)

dalam Pembelajaran

\begin{tabular}{|c|l|c|c|c|}
\hline NO & TINDAKAN & $\begin{array}{c}\text { KETERLAKSANAAN } \\
\text { DALAM } \\
\text { PEMBELAJARAN (\%) }\end{array}$ & KRITERIA & $\begin{array}{c}\text { INDIKATOR } \\
\text { KEBERHASILAN } \\
\geq 95 \%\end{array}$ \\
\hline 1 & Siklus I & 80,77 & Sangat tinggi & Belum memenuhi \\
\hline 2 & Siklus II & 96,15 & Sangat tinggi & Belum memenuhi \\
\hline 3 & Siklus III & 100,00 & Sangat tinggi & memenuhi \\
\hline
\end{tabular}

Berdasarkan tabel 1 keterlaksanaan pembelajaran pada siklus I mencapai 80,77 \% tetapi mencapai kreteria sangat tinggi. Hal ini terjadi karena berdasarkan hasil observasi pada pertemuan 1 ada kegiatan guru yang tidak dilaksanakan yaitu guru tidak memberi kesempatan kepada siswa untuk bertanya, menjawab pertanyaan dan memberikan tanggapan, guru tidak memberikan penguatan atau umpan balik, dan tidak membimbing siswa menyusun kesimpulan. Hal ini disebabkan karena siswa masih merasa malu untuk bertanya, menjawab pertanyaan dan memberikan tanggapan. Dan mengapa dari beberapa kegiatan pembelajaran ada yang tidak dilaksanakan karena guru terlalu banyak memberikan waktu diskusi kepada siswa, tanpa menggunakan waktu yang telah tercantum pada RPP sehingga guru tidak memiliki waktu untuk memberikan penguatan atau umpan balik dan tidak sempat membimbing siswa menyusun kesimpulan. Di pertemuan ke dua, ternyata hal serupa terulang kembali, guru masih tidak memberikan penguatan atau umpan balik kepada siswa dan tidak membimbing siswa menyusun kesimpulan.

Setelah diadakan refleksi pada siklus I, hal ini diperbaiki sebelum melangkah ke siklus II. Ternyata pada siklus II keterlaksanaan pembelajaran mencapai 96,15 dengan kreteria sangat tinggi, artinya telah tercapai indikator keberhasilan penelitian, namun masih ada satu kegiatan guru yang belum dilaksanakan yaitu guru tidak sempat membimbing siswa menyusun kesimpulan. Dan setelah melalui perbaikan didalam pembelajaran pada 
siklus II maka keterlaksanaan pembelajaran pada siklus III mencapai $100 \%$ dengan kreteria sangat tinggi. Berdasarkan hal tersebut maka dapat disimpulkan bahwa keterlaksanaan pembelajaran Think Talk Write (TTW)

telah seluruhnya dilakukan guru. Dan telah mencapai indikator keberhasilan.

B. Aktivitas siswa

Aktivitas siswa dalam pembelajaran menggunakan Think Talk Write (TTW) seperti terlihat pada tabel 2.

Tabel 2

Observasi Aktivitas Siswa Dalam Pembelajaran

Menggunakan Think Talk Write (TTW)

\begin{tabular}{|c|c|c|c|c|}
\hline NO & ASPEK YANG DIAMATI & $\begin{array}{l}\text { SIKLUS } \\
\text { I (\%) }\end{array}$ & $\begin{array}{l}\text { SIKLUS } \\
\text { II (\%) }\end{array}$ & $\begin{array}{l}\text { SIKLUS } \\
\text { III (\%) }\end{array}$ \\
\hline 1 & Kesiapan belajar & 85,00 & 97,50 & 100,00 \\
\hline 2 & Mendengarkan dan Memperhatikan penjelasan guru & 90,00 & 100,00 & 100,00 \\
\hline 3 & $\begin{array}{l}\text { Siwa menuangkan ide dalam memecahkan masalah dlm } \\
\text { LDS secara individu (think) }\end{array}$ & 40,00 & 75,00 & 97,50 \\
\hline 4 & $\begin{array}{l}\text { Siswa berdiskusi dan saling menukar gagasan dalam } \\
\text { kelompok (Talk) }\end{array}$ & 65,00 & 85,00 & 100,00 \\
\hline 5 & $\begin{array}{l}\text { Siswa menuliskan jawaban atas permasalahan yang } \\
\text { terdapat di LDS (Write) }\end{array}$ & 50,00 & 80,00 & 100,00 \\
\hline 6 & Mempresentasikan hasil diskusi & 50,00 & 87,50 & 92,50 \\
\hline 7 & Menyampaikan atau mengemukakan pendapat & 52,50 & 67,50 & 82,50 \\
\hline 8 & Menyanggah pertanyaan saat diskusi & 22,50 & 57,50 & 82,50 \\
\hline 9 & Mengajukan dan aktif pertanyaan & 22,50 & 52,50 & 77,50 \\
\hline 10 & Menjawab pertanyaan & 20,00 & 55,00 & 82,50 \\
\hline & RATA-RATA AKTIVITAS SETIAP SIKLUS (\%) & 49,75 & 75,75 & 91,50 \\
\hline & KRETERIA & $\begin{array}{c}\text { Cukup } \\
\text { aktif }\end{array}$ & $\begin{array}{c}\text { Sangat } \\
\text { aktif }\end{array}$ & $\begin{array}{c}\text { Sangat } \\
\text { aktif }\end{array}$ \\
\hline
\end{tabular}

Tabel 2 menunjukkan bahwa aktivitas siswa pada siklus I mencapai rata-rata 49,75\% dengan kreteria cukup aktif. Hal ini karena selain pada aspek kesiapan belajar, mendengarkan dan memperhatikan penjelasan guru, maka pada aspek no $3,4,5,6,7,8,9,10$ aktivitas siswa dalam Pembelajaran Think Talk Write (TTW) menunjukkan dibawah indikator keberhasilan penelitian. Hal ini disebabkan karena siswa belum terbiasa melakukan diskusi dengan model pembelajaran Think Talk Write (TTW), dan siswa masih malu untuk menyampaikan pendapat, menyanggah pertanyaan, bertanya, menjawab pertanyaan.

Setelah diadakan perbaikan maka pada siklus II aktivitas siswa meningkat menjadi $75,75 \%$ dengan kreteria sangat aktif. Namun demikian untuk beberapa aspek pada poin $7,8,9,10$ yang merupakan rangkaian dari model pembelajaran Think Talk Write (TTW) masih ada yang belum mencapai indikator keberhasilan 75\%.

Setelah diadakan perbaikan maka pada siklus III terlihat adanya peningkatan aktivitas siswa dalam Pembelajaran Think Talk Write (TTW) 
sebesar 91,50\% dengan kreteria sangat aktif. Hal ini menunjukkan bahwa aktivitas siswa dalam Pembelajaran Think Talk Write (TTW) telah memenuhi indikator keberhasilan 75\% untuk setiap aspek kegiatan siswa. Dengan demikian dapat disimpulkan bahwa model Pembelajaran Think Talk Write (TTW) dapat meningkatkan aktivitas belajar siswa. Dan telah menunjukkan indikator keberhasilan penelitian.

\section{Hasil belajar siswa}

Berdasarkan tabel 3, rata-rata tes formatif siswa pada siklus I 66,40 dengan ketuntasan klasikal 55\% hal ini belum menunjukkan indikator keberhasilan karena ada 9 siswa yang memperoleh nilai dibawah KKM 65.

Tabel 3

Hasil Tes Formatif

\begin{tabular}{|c|l|c|c|c|c|}
\hline NO & TINDAKAN & RATA-RATA & TUNTAS & $\begin{array}{c}\text { TIDAK } \\
\text { TUNTAS }\end{array}$ & $\begin{array}{c}\text { KETUNTASAN } \\
\text { KLASIKAL } \geq 75 \%\end{array}$ \\
\hline 1 & Siklus I & 66,40 & 11 & 9 & $55 \%$ \\
\hline 2 & Siklus II & 72,15 & 14 & 6 & $70 \%$ \\
\hline 3 & Siklus III & 83,55 & 20 & 0 & $100 \%$ \\
\hline
\end{tabular}

Setelah diadakan refleksi pada siklus I, maka rata-rata tes formatif siswa meningkat menjadi 72,15 dengan ketuntasan klasikal $75 \%$. Hal ini belum menunjukkan indikator keberhasilan. Dan masih terdapat 6 siswa yang memiliki nilai dibawah KKM sekolah 65.

Dan setelah diadakan perbaikan, maka pada siklus III rata-rata tes formatif siswa meningkat menjadi 83,55 dengan ketuntasan klasikal $100 \%$. Hal ini telah menunjukkan indikator keberhasilan penelitian. Dengan demikian dapat disimpulkan bahwa model Pembelajaran Think Talk Write (TTW) dapat meningkatkan hasil belajar siswa.

D. Respon siswa

Tabel 4 merupakan hasil observasi respon siswa terhadap pembelajaran Think Talk Write (TTW).

Tabel 4

Respon Siswa Terhadap Pembelajaran Think Talk Write (TTW)

\begin{tabular}{|c|l|c|c|}
\hline NO & PERNYATAAN & JUMLAH & PERSENTASE \\
\hline 1 & Sangat senang & 18 & $95 \%$ \\
\hline 2 & Senang & 2 & $5 \%$ \\
\hline 3 & Kurang senang & - & - \\
\hline 4 & Tidak senang & - & - \\
\hline
\end{tabular}

Dari tabel tersebut dapat disimpulkan bahwa dari 20 orang siswa yang mengisi respon siswa terhadap pembelajaran TTW, maka 95\% mengatakan sangat senang jika 
didalam proses pembelajaran guru menggunakan model pembelajaran Think Talk Write (TTW) untuk membahas persoalan matematika pada materi persamaan linier dua variabel. Dan 5\% mengatakan senang jika didalam proses pembelajaran guru menggunakan model pembelajaran Think Talk Write (TTW) untuk membahas persoalan matematika pada materi persamaan linier dua variabel dan tidak ada siswa yang menyatakan kurang senang ataupun tidak senang dengan pembelajaran menggunakan Think Talk Write (TTW). Hal ini menunjukkan respon siswa terhadap model pembelajaran Think Talk Write (TTW) menunjukkan respon yang positif, yaitu minimal $65 \%$ siswa menyatakan "Ya" pada setiap pernyataan respon siswa. Dengan demikian dapat disimpulkan bahwa siswa sangat senang jika model Pembelajaran Think Talk Write (TTW) digunakan dalam proses pembelajaran matematika pada materi Persamaan Linier Dua Variabel.

\section{Simpulan dan Saran}

\section{Simpulan}

Berdasarkan hasil dari penelitian tindakan kelas yang telah dilakukan, maka diperoleh kesimpulan sebagai berikut :

1. Keterlaksanaan model pembelajaran Think Talk Write (TTW) pada materi Persamaan Linier Dua Variabel telah dilakukan oleh guru seluruhnya dari 80,77 $\%$ pada siklus I, dan $96,15 \%$ pada siklus II, mengalami peningkatan $100 \%$ pada siklus III dengan kriteria sangat tinggi.

2. Aktivitas siswa kelas VIIIA SMP Negeri 6 Pelaihari dalam Model Pembelajaran Think Talk Write (TTW) pada materi Persamaan Linier Dua Variabel meningkat dari 49,75\% pada siklus I, dan
75,75 \% pada siklus II menjadi 91,50\% pada siklus III dengan kriteria sangat aktif.

3. Hasil belajar siswa kelas VIIIA SMP Negeri 6 Pelaihari pada materi persamaan linier Dua Variabel setelah menggunakan model pembelajaran Think Talk Write (TTW) menunjukkan adanya peningkatan dari rata-rata 66,40 pada siklus I dengan ketuntasan klasikal $55 \%$ dan rata-rata 72,15 pada siklus II dengan ketuntasan klasikal $70 \%$ menjadi rata-rata 83,55 dengan ketuntasan klasikal 100\%.

4. Pembelajaran matematika melalui Think Talk Write (TTW) telah menunjukkan respon positif siswa kelas VIIIA SMP Negeri 6 Pelaihari terhadap proses pembelajaran materi pada materi Persamaan Linier Dua Variabel. $95 \%$ siswa menyatakan sangat senang belajar materi persamaan linier Dua Variabel dengan menggunakan model pembelajaran Think Talk Write (TTW).

Dengan demikian secara umum dapat disimpulkan bahwa Model Pembelajaran Think Talk Write (TTW) dapat meningkatkan proses dan hasil belajar matematika siswa kelas VIIIA SMP Negeri 6 Pelaihari Pada Materi Persamaan Linier Dua Variabel.

\section{Saran}

Saran yang dapat peneliti kemukakan berdasarkan hasil penelitian tindakan kelas ini adalah sebagai berikut :

1. Model pembelajaran Think Talk Write (TTW), dapat digunakan untuk meningkatkan aktifitas dan keterlibatan siswa dalam proses pembelajaran.

2. Pembelajaran matematika dengan menggunakan Model Pembelajaran Think Talk Write (TTW) merupakan salah satu alternatif yang dapat digunakan oleh guru 
untuk dapat meningkatkan proses dan hasil belajar siswa.

3. Penggunaan Model Pembelajaran Think Talk Write (TTW) pada pembelajaran matematika dapat dipilih materi yang sesuai, hal ini untuk lebih meningkatkan hasil pembelajaran materi tersebut

4. Model pembelajaran Think Talk Write (TTW) juga dapat diterapkan pada mata pelajaran lain.

5. Perlu dilakukan penelitian sejenis dengan tempat dalam karasteritik yang berbeda.

\section{Daftar Pustaka}

Anas, Sudijono. (1996). Pengantar Evaluasi Pendidikan. Jakarta: PT Raja Grafindo Persada.

Atmono, Dwi. (2009). Panduan Praktis Penelitian Tindakan Kelas. Banjarbaru : Scripta Cendikia.

Hamdayana, Jumanta. (2014). Model dan Metode Pembelajaran Kreatif dan Berkarakter. Bogor: Ghalia Indonesia.

Huda, Miftahul. (2014). Model-Model Pengajaran dan Pembelajaran Isu-Isu Metodis dan Paradigmatis. Yogyakarta: Pustaka Pelajar.

Isrok'atun, Rosmala Amelia. (2018). ModelModel Pembelajaran Matematika. Jakarta: PT.Bumi Aksara.

Kunandar. (2008). Langkah Mudah Penelitian Tindakan Kelas Sebagai Pengembangan Profesi Guru. Jakarta: Rajawali Pers.

Rusman. (2011). Model-Model Pembelajaran Mengembangkan Profesionalisme Guru. Jakarta: Rajawali Pers. 